\title{
Determinants of New Consumer Product Success or Failure in Nepal
}

\author{
Bed Nath Sharma
}

\begin{abstract}
This study is concerned to know the determinants of new product success or failure in Nepalese market. New product success or failure is measured financially. The main determinants of new product success are: product features, price, quality promotion, market information, service to customers, wide distribution channel etc. Most of the new products are sick or partially successful due to lower quality, high competition, improper pricing, weak promotional efforts, ineffective advertisement media, irregular supply of goods, financial inadequacy, insufficient market research, less beneficial to the users etc. Few new products are successful which is indicated by market growth, competitive position maintained, profitability etc.
\end{abstract}

Key words: new product development, consumer product

IN TODAY'S GLOBALLY COMPETITIVE world, successful new product planning and development is a challenge to the industry. It is a creative function within a business organization. Modern concept of new product planning and development is the involvement of multi-disciplinary team from idea generation to commercialization. In Nepal, competition is increasing day by day. Many products of same use are available in the market. Product failure rate is also increasing. Many products are in sick situation. Thus, the study is concerned on 'What are the causes of new product success or failure in Nepal?"

\section{Study Methods}

The study has been based on descriptive (survey cum analytical) research design. Case study approach was followed on different consumer products. It is based on a field survey through questionnaire administration and personal interview. Sample products covered are 10 Soap, 8 Biscuit, 6 Noodles, 5 Cigarettes and 3 Cold Drinks. Thus total sample products are 32 from 18 different manufacturing units of Nepal. Sources of information are mainly 18 line managers and 13 top-level management personnel. The line managers represent 32 new products and the top management represents 23 new products. All tables are not presented but they are available with the writer.

\section{Theory}

Management of new product development has identified co-ordination and communication across specialized activity areas as critical to development speed, productivity and product quality. The success of projects also hinges upon their ability to learn from past integrative execute their integration experience. Project may be able to execute their integration most effectively when they deeply understand and potential interactions across different knowledge domains through past development experiences. Prior experience bases are seen to prevent projects from successfully introducing products for new markets or unfamiliar customers. Managers have to explicitly manage knowledge flows from previous projects in accordance with the specific objectives for each new product development projects (Aoshima 1996). Management and environmental variables, which impacted on product 
innovation. Management variables are: education, training management style, planning, technology/production, product/market mix, research and development, product quality and risk. Whereas, environmental variables are: market change, competitive turbulence, customer base, product life-cycle, technological innovativeness, and labour-force and finance (Romano 1990).

New product success is defined as a communicative index of both degree of financial success of the entire new product program and the degree of financial success of a particular product introduction (Calantone, diBenedetto and Bhoovarghavan 1994). Key factors affect product outcome are: (1) quality of R \& D organization (2) technical performance of the product (3) products value to the customer (4) the synergy of the new product with the firms existing competences and (5) management support during the product development and introduction processes. (6) competence of the marketing and manufacturing organizations and market factors (7) competitiveness and (8) size and rate of growth of the target market (Zirger and Maidique 1990).

If the risk of new product development is to be reduced there needs to be greater understanding of the determinants of success and failure in this endeavor and continuing effort to apply such knowledge in product innovation management (Dwyer and Mellor 1991). Despite the importance of new product development to firms and to national economies, new products continue to have high failure rates. Only about half of the expenditure by the U.S. business on new product development and commercialization tends to be financially successful and for every seven concepts that survive the screening stage and enter the new product process, only one results in commercial success (Booz-Allen and Hamilton 1982).

According to Booz-Allen and Hamilton (1982), for every 100 projects that enter development, 63 are killed! of the 37 remaining Go projects, 25 became commercial success and 12 became commercial failure in the market (Cooper and Klenschmidt 1990).

Large manufacturing companies have of range of product lines, and successfully introduced new product over time. To adapt to changing customer needs, they may replace existing product at regular intervals and add new product line (Aoshima 1996). From a managerial perspective, because the majority (89\%) of new product introduction activity appears to come from line extension. Major finding of success determinants of line extensions are as follows:

1) Line extensions of strong brands are more successful than extension of weak brands.

2) Line extensions of symbolic brand enjoy greater market success than those of less symbolic brands.

3) Line extension that received strong advertisement and promotional support are more successful than those extensions that receive manager support.

4) Line extensions entering earlier into a product subcategory are more successful than extensions entering later, but only if they are extensions of strong brands.

5) Firm size and marketing competencies also play a part in an extension's success.

6) Earlier line extensions have helped in the market expansion of the present brand and,

7) Incremental sales generated by line extensions may more than compensate for the loss in sales due to cannibalization (Reddy, Holak and Bhat 1994). A new product research investigated over 1000 new firms in Europe and North America over the 
last two decades concluded the following eight key drivers for new product success:

1. The success factor is the unique superior product;

2. A strong market orientation;

3. Success or failure is often decided in the first few stages of the project;

4. Sharp and early product definition;

5. The cross-functional team approach;

6. Focus is central to success;

7. Quality of execution is paramount;

8. A multi-stage-and-gate "Game Plan" outcomes some of the deficiencies: (Maidique and Zirger, 1984).

The vast literature on new product success and failure brings to light a host of factors that influence success. Among them main sets are: The need for interdisciplinary inputs, which indicates the meet of professionals who provide education, training and certification. Second is: The need for quality inputs to the process, which indicates technical and marketing information including customer and supplier inputs accurately and timely for NPD. And thirdly: The need for speed in the process- is related with the management quickly to capitalize new product opportunity before competitors do so (Hart and Baker 1994).

New product development requirements are: High efficiency products; at the right time, at the right cost, with the right technical performance. Efficiency requirements of the second order satisfactory; ease of assembly and ease of maintenance. High effectiveness products; to the right customer and with the right design (Carlerson 1991).

New product process impacts the success rates of new products. Institutions with good success rates do have better over all management of their new product process (Edgett 1996). High costs of new product development encourage manufacturers and researchers to examine ways of increasing the potential success of new innovations (Song, Neeley and Zhao 1996).

A number of researchers have found a positive relationship between new product success and the integration of activities of two of the functional units involved in new product process- R\&D and marketing (Rochford and Ruddins 1997). Successful new product development partially may depend on the ability to understand technical and market knowledge embodied in existing products, and adopts this knowledge to support new product development (Iansiti 1995). Inter functional co-ordination and collaboration between $\mathrm{R} \& \mathrm{D}$ and marketing is crucial to the success of the new product development process (Song, Neeley and Zhao 1996).

\section{Determinants Analysis on New Product Success or Failure}

New product success or failure is measured in terms of corporate expectations or objectives achievement. Successful product achieves financial success or growth, but the situation of failed product is just opposite. Situation relating to success or failure of Nepalese consumer products is presented in this analysis. The experience on determinants of new product success are responsibility assigned to study new product success or failure, practice of market study before developing the new product, costing and cost control practice, sales trend of new product, responsible authority for product success or failure, feelings on product line extension, variables considered for new product success, practice of financial mea- 
surement of product success etc.

\subsection{Perception of Top Level Management}

Most of the consumer product industries (95.66\%) have done sufficient market study before new product development. Experiences of management on determinants of new product success are:

(a) New idea (b) Convenience (c) Consistency (d) Value of money (e) Good product quality (f) Market segmentation (g) Promotional efforts (h) Attractive packaging (i) Distribution plan (j) Competitive as well as cheaper price (k) Credit facility (l) Scheme to the consumer (m) Market information collection and immediately following up (n) Better service to customer (o) Widened distribution channel (p) Suitable discount structure (q) Market expansion (r) Conversion of consumer's class, etc.

\section{Causes of new product failure in the experience of management}

(a) Inconsistent/week quality (b) Narrow distribution channel (c) More new product entrance (d) Ineffective price structure (e) Weak promotional efforts (f) Diversion of target customers into the brand substitute product (g) High pricing (h) Improper pricing (i) Weak competition (j) Improper media plan (k) Insufficient sales promoter (l) Irregular supply (m) No study of consumer behavior (n) Less awareness of consumer (o) Financial inadequacy (p) Inefficient media selection for advertisement (q) No study of market segment targeted (r) No tracking of competitor's more (s) Taste unlike/consumer rejection (t) Competitor's market hold (u) Unhealthy competition (v) Consumer psychology, etc.

Total 36 consumer products are succeeded out of 66 new product developed by top level management in their management responsibility holding duration in the sampled industries. There is reward and punishment practice in product success or failure is partial, because 43.48 percent answer is positive and 56.52 percent answer is negative out of total responses. Similarly, 78.27 percent (18 responses out of 23) respondents feel that the scope of consumer products in Nepal is wider but 21.73 percent (5 responses out of 23) feel that the scope is not wider in Nepal. Thus, majority respondents feel that the scope of consumer products is wider in Nepal.

\subsection{Opinion of Line Manager}

There is not inter-functional coordination and collaboration in between R \& D and marketing of new product in most of the soap industry of Nepal. But this practice is seen in most of the biscuit, noodles, cigarette and cold drink industries of Nepal. In total also 68.75 percent ( 22 out of 32 responses) viewed that there is practice of inter-functional coordination and collaboration in between R \& D and marketing of new product. Only 31.25 percent (10 out of 32 responses) viewed that there is not such practice.

Most of the new products of soap and noodles industries are partially successful in the market. But most of the new products of cigarette industry are not successful. Most of the new product of biscuit industry is successful. In total also most of the new product 53.12 percent (17 responses out of 32 ) are partially successful, 31.25 percent (10 responses out of 32 ) are successful and 15.62 percent (5 out of 32 respondents) are not successful. It proves that most of the consumer new products $(53.12+15.62=68.74$ percent $)$ are not successful in the market. In other words, most of the new products are sick.

Around sixty-nine percent (22 responses out of 32 ) consumer new product industries are not using the product development model but only 31.25 percent are using the model. 
Most of the respondents of consumer (59.38 percent) product industries except biscuit industry do not know anything about the global issue of new products management.

According to following Table 1 shows that all given factors of new product success are seen considered, because response is not nil in total figure of all sampled products. Among all given factors, pricing of product with compared to competition, strong market orientation including promotion and customer focus, quality of new product development process implementation and necessary correction, overall competitive position of the product and adequate trained sales force factors of new product success are seen highly considered in total sampled consumer product industries of Nepal.

Table 1: Consideration of New Product Success Factors

\begin{tabular}{|c|c|c|c|c|c|c|c|}
\hline S.N. & Factors & Soap & Biscuit & Noodles & Cigarette & Cold Drink & Total \\
\hline a. & Unique superior and competitive useful product & $\begin{array}{c}8 \\
(6.67)\end{array}$ & $\begin{array}{c}3 \\
(6)\end{array}$ & $\begin{array}{c}5 \\
(6.94)\end{array}$ & $\begin{array}{c}5 \\
(5.62)\end{array}$ & $\begin{array}{c}1 \\
(2.78)\end{array}$ & $\begin{array}{c}22 \\
(5 . .99)\end{array}$ \\
\hline b. & $\begin{array}{l}\text { Strong market orientation (study and test of } \\
\text { market) including promotion and customer focus }\end{array}$ & $\begin{array}{c}10 \\
(8.33)\end{array}$ & $\begin{array}{c}2 \\
(4)\end{array}$ & $\begin{array}{c}5 \\
(6.94)\end{array}$ & $\begin{array}{c}5 \\
(5.62)\end{array}$ & $\begin{array}{c}3 \\
(8.33)\end{array}$ & $\begin{array}{c}25 \\
(6 . .81)\end{array}$ \\
\hline c. & $\begin{array}{l}\text { The cross functional (combination of } \\
\text { different functions approach) }\end{array}$ & $\begin{array}{c}3 \\
(2.50)\end{array}$ & $\begin{array}{l}3 \\
(6)\end{array}$ & $\begin{array}{c}2 \\
(2.78)\end{array}$ & $\begin{array}{c}2 \\
(2.24)\end{array}$ & $\begin{array}{c}1 \\
(2.78)\end{array}$ & $\begin{array}{c}11 \\
(3.00)\end{array}$ \\
\hline d. & $\begin{array}{l}\text { Focus is central to success (sharper evaluation } \\
\text { and sound decision of technical steps) }\end{array}$ & $\begin{array}{c}2 \\
(1.67)\end{array}$ & $\begin{array}{l}1 \\
(2)\end{array}$ & $\begin{array}{c}3 \\
(4.17)\end{array}$ & $\begin{array}{c}5 \\
(5.62)\end{array}$ & $\begin{array}{c}2 \\
(5.56)\end{array}$ & $\begin{array}{c}13 \\
(3.54)\end{array}$ \\
\hline e. & $\begin{array}{l}\text { Quality of execution (new product development } \\
\text { process implementation and necessary correction) }\end{array}$ & $\begin{array}{c}8 \\
(6.67)\end{array}$ & $\begin{array}{c}5 \\
(10)\end{array}$ & $\begin{array}{c}4 \\
(5.56)\end{array}$ & $\begin{array}{c}5 \\
(5.62)\end{array}$ & $\begin{array}{c}2 \\
(5.56)\end{array}$ & $\begin{array}{c}24 \\
(6.54)\end{array}$ \\
\hline f. & $\begin{array}{l}\text { A multi-stage and gate-game plan outcomes } \\
\text { some of the deficiencies (to observe the whole new } \\
\text { product process to know that what is good or bad) }\end{array}$ & $(0.83)$ & (4) & (4.17) & $(5.62)$ & (2.78) & $(3.27)$ \\
\hline g. & Home work before starting the development & $\begin{array}{c}5 \\
(4.17)\end{array}$ & $\begin{array}{c}4 \\
(8)\end{array}$ & $\begin{array}{c}4 \\
(5.56)\end{array}$ & $\begin{array}{c}5 \\
(5.62)\end{array}$ & $\begin{array}{c}3 \\
(8.33)\end{array}$ & $\begin{array}{c}21 \\
(5.72)\end{array}$ \\
\hline h. & $\begin{array}{l}\text { Coordination of firms } \mathrm{R} \& \mathrm{D} \text {, production and } \\
\text { marketing function }\end{array}$ & $\begin{array}{c}2 \\
(1.67)\end{array}$ & $\begin{array}{c}8 \\
(16)\end{array}$ & $\begin{array}{c}3 \\
(4.17)\end{array}$ & $\begin{array}{c}5 \\
(5.62)\end{array}$ & $\begin{array}{c}2 \\
(5.56)\end{array}$ & $\begin{array}{c}20 \\
(5.44)\end{array}$ \\
\hline i. & High level management support up to launch stage & $\begin{array}{c}7 \\
(5.83)\end{array}$ & $\begin{array}{c}1 \\
(2)\end{array}$ & $\begin{array}{c}5 \\
(6.94)\end{array}$ & $\begin{array}{c}5 \\
(5.62)\end{array}$ & $\begin{array}{c}3 \\
(8.33)\end{array}$ & $\begin{array}{c}21 \\
(5.72)\end{array}$ \\
\hline j. & $\begin{array}{l}\text { Production process and technology used is } \\
\text { superior and effective }\end{array}$ & $\begin{array}{c}7 \\
(5.83)\end{array}$ & $(0)$ & $\begin{array}{c}5 \\
(6.94)\end{array}$ & $\begin{array}{c}5 \\
(5.62)\end{array}$ & $\begin{array}{c}2 \\
(5.56)\end{array}$ & $\begin{array}{c}21 \\
(5.44)\end{array}$ \\
\hline k. & High contribution margin to the firm & $\begin{array}{c}7 \\
(5.83)\end{array}$ & $\begin{array}{c}1 \\
(2)\end{array}$ & $\begin{array}{c}1 \\
(1.39)\end{array}$ & $\begin{array}{c}- \\
(0)\end{array}$ & $\begin{array}{c}1 \\
(2.78)\end{array}$ & $\begin{array}{c}19 \\
(5.72)\end{array}$ \\
\hline 1. & Seniority an authority of manager & $\begin{array}{c}6 \\
(5.0)\end{array}$ & $\begin{array}{c}- \\
(0)\end{array}$ & $\begin{array}{c}3 \\
(4.17)\end{array}$ & $\begin{array}{c}2 \\
(2.24)\end{array}$ & (0) & $\begin{array}{c}11 \\
(5.17)\end{array}$ \\
\hline $\mathrm{m}$ & Pricing of product with compared to competitor & $\begin{array}{c}9 \\
(7.50)\end{array}$ & $\begin{array}{c}6 \\
(12)\end{array}$ & $\begin{array}{c}5 \\
(6.94)\end{array}$ & $\begin{array}{c}5 \\
(5.62)\end{array}$ & $\begin{array}{c}3 \\
(8.33)\end{array}$ & $\begin{array}{c}10 \\
(2.72)\end{array}$ \\
\hline $\mathrm{n}$. & Overall competitive position of the product & $\begin{array}{c}10 \\
(8.33)\end{array}$ & $\begin{array}{c}4 \\
(8)\end{array}$ & $\begin{array}{c}2 \\
(2.78)\end{array}$ & $\begin{array}{c}5 \\
(5.62)\end{array}$ & $\begin{array}{c}2 \\
(5.56)\end{array}$ & $\begin{array}{c}23 \\
(6.27)\end{array}$ \\
\hline o. & $\begin{array}{l}\text { Gaps between manager's belief and reality (managers } \\
\text { are not focusing to important elements of success) }\end{array}$ & $\begin{array}{l}\mathrm{s} \\
(0)\end{array}$ & $\begin{array}{l}1 \\
(2)\end{array}$ & $\begin{array}{c}1 \\
(1.39)\end{array}$ & $\begin{array}{c}3 \\
(3.37)\end{array}$ & $\begin{array}{ll}- \\
(0)\end{array}$ & $\begin{array}{c}5 \\
(1.36)\end{array}$ \\
\hline p. & Good knowledge of manager about project & $\begin{array}{c}5 \\
(4.17)\end{array}$ & $\begin{array}{c}1 \\
(2)\end{array}$ & $\begin{array}{c}3 \\
(4.17)\end{array}$ & $\begin{array}{c}5 \\
(5.62)\end{array}$ & $\begin{array}{c}2 \\
(5.56)\end{array}$ & $\begin{array}{c}16 \\
(7.63)\end{array}$ \\
\hline q. & $\begin{array}{l}\text { Matching project needs and management engineering } \\
\text { research skill and resources }\end{array}$ & g, - & $\begin{array}{c}1 \\
(2)\end{array}$ & $\begin{array}{c}4 \\
(5.56)\end{array}$ & $\begin{array}{c}5 \\
(5.62)\end{array}$ & $\begin{array}{c}1 \\
(2.78)\end{array}$ & $\begin{array}{c}11 \\
(3.00)\end{array}$ \\
\hline r. & Adequate trained sales force & $\begin{array}{c}9 \\
(7.50)\end{array}$ & $\begin{array}{c}3 \\
(5.56)\end{array}$ & $\begin{array}{c}4 \\
(5.61)\end{array}$ & $\begin{array}{c}5 \\
(5.55)\end{array}$ & $\begin{array}{c}2 \\
(1.36)\end{array}$ & $\begin{array}{c}23 \\
(6.27)\end{array}$ \\
\hline s. & Large and growing target market & $\begin{array}{c}8 \\
(6.67)\end{array}$ & $\begin{array}{c}2 \\
(6)\end{array}$ & $\begin{array}{c}4 \\
(5.55)\end{array}$ & $\begin{array}{c}2 \\
(2.24)\end{array}$ & $\begin{array}{c}2 \\
(5.55)\end{array}$ & $\begin{array}{c}16 \\
(4.36)\end{array}$ \\
\hline t. & A clear new product strategy & $\begin{array}{c}5 \\
(4.16)\end{array}$ & $\begin{array}{l}1 \\
\text { (4) }\end{array}$ & $\begin{array}{c}3 \\
(4.16)\end{array}$ & $\begin{array}{c}5 \\
(5.61)\end{array}$ & $\begin{array}{c}2 \\
(5.55)\end{array}$ & $\begin{array}{c}16 \\
(4.36)\end{array}$ \\
\hline u. & Adequate resources for new product development & $\begin{array}{c}8 \\
(6.67)\end{array}$ & $\begin{array}{l}1 \\
\text { (2) }\end{array}$ & $\begin{array}{c}3 \\
(4.16)\end{array}$ & $\begin{array}{c}5 \\
(5.61)\end{array}$ & $\begin{array}{c}1 \\
(2.78)\end{array}$ & $\begin{array}{c}18 \\
(4.91)\end{array}$ \\
\hline $\mathrm{v}$. & $\begin{array}{l}\text { Any other (please specify) } \\
\text { Total }\end{array}$ & $\begin{array}{c}- \\
120 \\
(100)\end{array}$ & $\begin{array}{c}- \\
50 \\
(100)\end{array}$ & $\begin{array}{c}- \\
72 \\
(100)\end{array}$ & $\begin{array}{c}- \\
89 \\
(100)\end{array}$ & $\begin{array}{c}- \\
36 \\
(100)\end{array}$ & $\begin{array}{c}- \\
367 \\
(100)\end{array}$ \\
\hline
\end{tabular}


Table 2 shows that, insufficient market research done prior to launch, product offered negligible saving and other benefits to users, product was not new to the market, inadequate promotion and advertising strategy etc. are the main causes of new product failure in consumer product industries.

Table 2: Causes of New Product Failure

\begin{tabular}{|c|c|c|c|c|c|c|c|}
\hline S.N & Causes & Soap & Biscuit & Noodles & Cigarette & Cold Drink & Total \\
\hline a. & Market was too competitive & $\begin{array}{c}5 \\
(13.16)\end{array}$ & $\begin{array}{c}3 \\
(21.43)\end{array}$ & $\begin{array}{c}1 \\
(4.76)\end{array}$ & $\begin{array}{l}- \\
(0)\end{array}$ & $\begin{array}{l}- \\
(0)\end{array}$ & $\begin{array}{c}9 \\
(10.23)\end{array}$ \\
\hline b. & $\begin{array}{l}\text { Insufficient market research was done prior to } \\
\text { launch }\end{array}$ & $\begin{array}{c}4 \\
(10.53)\end{array}$ & $\begin{array}{c}1 \\
(7.14)\end{array}$ & $\begin{array}{c}3 \\
(14.29)\end{array}$ & $\begin{array}{c}3 \\
(30)\end{array}$ & $\begin{array}{c}1 \\
(20)\end{array}$ & 12 \\
\hline c. & Product was not new to the market & $\begin{array}{c}4 \\
(10.53)\end{array}$ & $\begin{array}{c}3 \\
(21.43)\end{array}$ & $\begin{array}{c}2 \\
(20)\end{array}$ & $\begin{array}{c}2 \\
(0)\end{array}$ & $\begin{array}{c}- \\
(13.64)\end{array}$ & 11 \\
\hline d. & $\begin{array}{l}\text { Product offered negligible saving or other } \\
\text { benefits to users }\end{array}$ & $\begin{array}{c}6 \\
(15.78)\end{array}$ & (0) & $\begin{array}{c}3 \\
(9.52)\end{array}$ & $\begin{array}{c}3 \\
(30)\end{array}$ & $\begin{array}{c}- \\
(0)\end{array}$ & $\begin{array}{c}12 \\
(12.50)\end{array}$ \\
\hline e. & $\begin{array}{l}\text { Inadequate sales force allocation and lack of } \\
\text { required training }\end{array}$ & $\begin{array}{l}- \\
(0)\end{array}$ & $\begin{array}{c}- \\
(0)\end{array}$ & $(14.29)$ & $\begin{array}{c}- \\
(0)\end{array}$ & $\begin{array}{c}1 \\
(20)\end{array}$ & $\begin{array}{c}1 \\
(13.64)\end{array}$ \\
\hline f. & Inadequate promotion or advertising strategy & $\begin{array}{c}6 \\
(15.78)\end{array}$ & $\begin{array}{c}- \\
(0)\end{array}$ & $\begin{array}{c}2 \\
(0)\end{array}$ & $\begin{array}{c}2 \\
(20)\end{array}$ & $\begin{array}{c}1 \\
(20)\end{array}$ & $\begin{array}{c}11 \\
(1.14)\end{array}$ \\
\hline g. & Inadequate top management attention / support & $\begin{array}{c}- \\
(0)\end{array}$ & $\begin{array}{c}- \\
(0)\end{array}$ & $\begin{array}{c}3 \\
(14.29)\end{array}$ & $\begin{array}{c}- \\
(0)\end{array}$ & $\begin{array}{c}1 \\
(20)\end{array}$ & $\begin{array}{c}4 \\
(4.55)\end{array}$ \\
\hline h. & Technical problem & $\begin{array}{c}- \\
(0)\end{array}$ & $\begin{array}{c}2 \\
(14.29)\end{array}$ & $\begin{array}{c}- \\
(0)\end{array}$ & $\begin{array}{c}- \\
(0)\end{array}$ & $\begin{array}{c}- \\
(0)\end{array}$ & $\begin{array}{c}2 \\
(2.27)\end{array}$ \\
\hline i. & Poor timing of launch & $\begin{array}{c}3 \\
(7.89)\end{array}$ & $\begin{array}{c}- \\
(0)\end{array}$ & $\begin{array}{c}1 \\
(4.76)\end{array}$ & $\begin{array}{c}- \\
(0)\end{array}$ & $\begin{array}{c}1 \\
(20)\end{array}$ & $\begin{array}{c}5 \\
(5.68)\end{array}$ \\
\hline $\mathrm{j}$. & $\begin{array}{l}\text { Assigning inadequate resource to market } \\
\text { development }\end{array}$ & $\begin{array}{c}4 \\
(10.53)\end{array}$ & $\begin{array}{c}- \\
(0)\end{array}$ & $\begin{array}{c}1 \\
(4.76)\end{array}$ & $\begin{array}{c}- \\
(0)\end{array}$ & $\begin{array}{c}- \\
(0)\end{array}$ & $\begin{array}{c}5 \\
(5.68)\end{array}$ \\
\hline k. & Lack of genuine superiority of product & (0) & $\begin{array}{c}- \\
(0)\end{array}$ & $\begin{array}{c}1 \\
(4.76)\end{array}$ & $\begin{array}{l}- \\
(0)\end{array}$ & $\begin{array}{c}- \\
(0)\end{array}$ & $\begin{array}{c}1 \\
(1.14)\end{array}$ \\
\hline 1. & Lack of understanding of competitive position & $\begin{array}{c}2 \\
(5.26)\end{array}$ & $\begin{array}{c}1 \\
(7.14)\end{array}$ & $\begin{array}{c}- \\
(0)\end{array}$ & $\begin{array}{c}- \\
(0)\end{array}$ & $\begin{array}{c}- \\
(0)\end{array}$ & $\begin{array}{c}3 \\
(3.41)\end{array}$ \\
\hline $\mathrm{m}$. & Lack of organizational expertise & $\begin{array}{c}2 \\
(5.26)\end{array}$ & $\begin{array}{c}2 \\
(14.29)\end{array}$ & $\begin{array}{c}1 \\
(4.76)\end{array}$ & $\begin{array}{l}- \\
(0)\end{array}$ & $\begin{array}{c}- \\
\text { (0) }\end{array}$ & $\begin{array}{c}3 \\
(5.68)\end{array}$ \\
\hline $\mathrm{n}$. & Improper pricing & $\begin{array}{l}- \\
(0)\end{array}$ & $\begin{array}{c}- \\
(0)\end{array}$ & $\begin{array}{c}1 \\
(4.76)\end{array}$ & $\begin{array}{l}- \\
(0)\end{array}$ & $\begin{array}{l}- \\
(0)\end{array}$ & $\begin{array}{c}1 \\
(1.14)\end{array}$ \\
\hline o. & Poor market launch & $\begin{array}{c}2 \\
(5.26)\end{array}$ & $\begin{array}{c}2 \\
(14.29)\end{array}$ & $\begin{array}{c}2 \\
(9.52)\end{array}$ & (0) & $\begin{array}{c}- \\
\text { (0) }\end{array}$ & $\begin{array}{c}6 \\
(6.81)\end{array}$ \\
\hline p. & Insufficient support by channel & $\begin{array}{c}- \\
\text { (0) }\end{array}$ & $\begin{array}{c}- \\
\text { (0) }\end{array}$ & $\begin{array}{c}- \\
(0)\end{array}$ & $\begin{array}{l}- \\
\text { (0) }\end{array}$ & $\begin{array}{c}- \\
\text { (0) }\end{array}$ & $\begin{array}{c}- \\
(0)\end{array}$ \\
\hline q. & $\begin{array}{l}\text { Any others (please specify) } \\
\text { Total }\end{array}$ & $\begin{array}{c}- \\
38 \\
(100)\end{array}$ & $\begin{array}{c}- \\
14 \\
(100)\end{array}$ & $\begin{array}{c}- \\
21 \\
(100)\end{array}$ & $\begin{array}{c}- \\
10 \\
(100)\end{array}$ & $\begin{array}{c}- \\
5 \\
(100)\end{array}$ & $\begin{array}{c}- \\
88 \\
(100)\end{array}$ \\
\hline
\end{tabular}

\section{Results}

4.1 Companies, in general, have done market study before new product development. Management is also found to measure the new product success financially, and use past experience to manage the new product. Determinants of new product success mentioned by the respondents (top level management) are: new idea, convenience, consistency, value of money, good product quality, promotional efforts, attractive packaging, distribution plan, competitive as well as cheaper price, credit facility, scheme to the consumer, market information collection and immediate follow-up, better service to the customer, widened distribution channel, suitable discount structure, market expansion etc. The management also feel that the sales trend of most of the new products is increasing and view that the scope of consumer products is wide in Nepal. 
4.2 Causes of new product failures mentioned by the top level management are: inconsistent/ weak quality, narrow distribution channel, more new product entrance, ineffective price structure, weak promotional efforts, diversion of target customers into the brand substitute product, high pricing, weak competition, improper media plan, insufficient sales promoter, irregular supply, no study of consumer behavior, financial inadequacy, inefficient media selection for advertisement, taste not liked by consumers, competitors' market hold, unhealthy competition etc. Reward and punishment practice in product success or failure is in partial practice.

4.3 Most of the sampled firms have inter-functional coordination and collaboration in between R \& D and marketing activities of new products. Marketing managers agree with product line extension factors presented to them. Similarly, among the given new product success factors, highly considered are: pricing of products in comparison to the competitors, strong market orientation including promotion and costumer focus, quality of new product development process, implementation and necessary correction as well as adequate trained sales force. Most of the sample firms are using the indicators for new product success like; domestic market share growth, competitive position maintained in the market, targeted relative sales in rupees, profitability level, and opening new market by new product etc.

4.4 The line managers feel that the majority of new products are partially successful in the market or they are sick. Main causes of new product failures mentioned are: insufficient market research before launch, product offered negligible saving or benefits to the users, inadequate promotion or weak advertisement strategy, product was not new to the market, competitive market etc. Majority of them are not using any of the product development models. Most of the marketing managers are not aware of the global issues of new product management.

\section{Conclusions and Implications}

5.1 The industry measure the product's success or failure financially. Management views that the experience is very much useful to manage the new products. The main determinants of new product success are: product features, price, quality, promotional efforts, market information, service to the customers, wide distribution channel, product development process implementation etc. Most of the new products become sick or partially successful due to bad quality, high competition, improper pricing, weak promotional efforts, ineffective advertisement media, irregular supply of goods, financial inadequacy, insufficient market research, negligible benefit to the user etc. The respondents agree that both top and line mangers are responsible for new products success or failure. In the industry, few new products are perceived to be successful. The main indicators used for new product success are: market growth, competitive position maintained, sales target, profitability etc.

5.2. New product development model is not used. Scope of consumer product industries is viewed as wide, although new products success rate in Nepal is perceived to be very low.

5.3. New product success position in the market should be improved through detail analysis of present problem and weaknesses. Practice of functional coordination and collabora- 
tion in between $\mathrm{R} \& \mathrm{D}$ and marketing activities of new product in entire industries should be increased. Balanced analysis, evaluation and consideration of new product success factors are required in all manufacturing units. Similarly, they should use standard indicators to measure new product success.

5.4. It is suggested to be more careful towards the causes of new product failure. Use of complete model for new product development will be beneficial for the consumer product industries.

\section{REFERENCE}

Aoshima, Yaichi. Oct. 1996. Knowledge Retention and New Product Development Performance. Hitotsubashi Journal of Commerce and Management 31 : 13-58.

Carlsson Matts. Jan. 1991. Aspects of the Integration of Technical Functions for Efficient Product Development. $R$ \& D Management 21: 55-66.

Clantone, Roger J., C. Anthony di Benedetto and Sriraman Bhoovaraghavan. June 1994. Examining the Relationship between Degree of Innovation and New Product Success. Journal of Business Research 30: 143-148.

Cooper, R.G. \& E.J. Kleinschmidt. Oct. 1990. New Product Success Factors: A Comparison of 'Skills' Versus Successes and Failures. $R$ \& D Management 19 : 46-63.

Dwyer, Larry and Robert Mellor. Jan. 1991. New Product Process Activities and Project Out Comes. $R \& D$ Management 21: 31-42.

Edgett, Scott J. Nov. 1996. New Product Development Process for Commercial Financial Services. Industrial Marketing Management 25: 507-516.

Hart, Susan J. 1994. The Multiple Convergent Processing Model of New Product Development. International Marketing Review 11 : 77-92.

Iansiti, Marco. 1995. Shooting the Rapids: Managing Product Development in Turbulent.

Kleinschmidt, Elko J. and Robert G. Cooper. July 1995. The Relative Importance of New Product Success Determinants- Perception Versus Reality. R\&D Management 25: 281-298.

Ready, Srinivas K; Susan L. Holak and Subodh Bhat. May 1994. To Extend or Not to Extend Success Determinants of Line Extensions. Journal of Marketing Research 31: 243-262.

Rochford, Linda and William Rudelim. Jan. 1997. New Product Development Process. Industrial Marketing Management $26: 67-84$.

Romano, Claudio A. Jan. 1990. Identifying Factors which Influence Product Innovation: A Case Study Approach. Journal of Management Studies 27 : 75-95.

Song, X. Michael, Sabrina M. Neeley and Yuzhen Zhao. Nov. 1996. Managing R \& D- Marketing Integration in the New Product Development Process. Industrial Marketing Management 25:545-554.

Zirger, Billie Jo. and Modesto A. Maidique. July 1990. A Model of New Product Development: An Empirical Test. Management Science 36: 867-883. 